
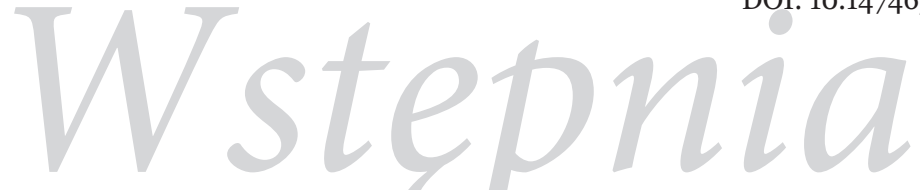

\title{
Siła przemocy
}

Do doświadczeniach dwóch wojen światowych, po niepowodzeniach takich projektów jak Liga Narodów, Trójprzymierze czy Trójporozumienie, w połowie XX wieku zdecydowano, że współpraca będzie najlepszym zabezpieczeniem przed kolejnym tragicznym w skutkach konfliktem. Wprawdzie rozwojowi tej współpracy, w ramach tworzenia Wspólnot Europejskich, towarzyszyła zimna wojna, jednak poziom napięcia i potencjalność konfliktu angażującego wiele państw udało się znacząco zmniejszyć. Kiedy na przełomie lat 80. i 90. ogłaszano koniec zimnowojennej rywalizacji i zwycięstwo zachodniej demokracji oraz jej wartości (z których za jedną z najważniejszych uważa się pokój), wydawało się, że jedyną siłą napędową relacji pomiędzy poszczególnymi państwami pozostaną konsensus, kompromis, oraz współpraca. Koniec historii to koniec wojen, rywalizacji, konfliktów. Jak złudne okazały się te twierdzenia, stało się jasne już kilka lat później. Świat bez konfliktów okazał się być niemożliwym.

Dziś, blisko trzydzieści lat po przełomie, który miał zapoczątkować erę powszechnego pokoju, coraz wyraźniej wybrzmiewają pytania o skuteczne sposoby rozwiązania konfliktów między państwami. Pojawiają się one głównie dlatego, że nie wszystkie strony sporów chcą kierować się zasadami, które miały zapewnić ich rozwiązywanie bez odwoływania się do przemocy. Stosowanie siły, ataki terrorystyczne, brak gotowości do udziału w jakichkolwiek rozmowach, to tylko niektóre z metod, którymi posługuje się np. tzw. Państwo Islamskie. Żadne negocjacje, czy międzynarodowe porozumienia nie rozwiążą problemu rosnącej w siły organizacji, której celem jest budowa własnego państwa na terenach, na których organizmy państwowe już istnieją. Kilkustronne negocjacje oraz próby pokojowego, w oparciu o wypracowane wcześniej standardy, rozwiązania sporu nie przyniosły również efektu w przypadku konfliktu pomiędzy Federacją Rosyjską a Ukrainą. Rosja anektowała część ukraińskiego terytorium, pomimo tego, że integralność Ukrainy gwarantowana była przez największe i 
najsilniejsze państwa w ramach Memorandum Budapesztańskiego. Wojska Federacji Rosyjskiej zostały również zaangażowane po jednej ze stron w ramach wojny we wschodniej części Ukrainy, pomimo, że Rosja oficjalnie zaprzecza swojemu udziałowi w tym konflikcie. Oczywiście, znacznie słabsza pod względem militarnym i borykająca się z ogromnym gospodarczym kryzysem Ukraina mogła odwołać się w tej sytuacji do społeczności międzynarodowej i wypracowanych wcześniej procedur, co uczyniła, jednak brak realizacji kolejnych punktów porozumień mińskich ${ }^{1}$ każe zadać pytanie o skuteczność pozasiłowych metod rozwiązywania konfliktów.

Wydawało się, że przynajmniej Europa, biorąc pod uwagę poziom rozwoju współpracy we wszystkich możliwych sferach, nie znajdzie się już w sytuacji, w której to przemoc i siła będą wskazywały na zwycięzcę konfliktu. Jednak konflikt, który wciąż trwa na wschodzie Ukrainy, a który poprzedziła aneksja przez Rosję części terytorium Ukrainy, poddają pod poważną wątpliwość wypracowane przez państwa europejskie reguły i zabezpieczenia. Otwarte pozostaje zatem pytanie, czy druga dekada XXI wieku będzie początkiem powrotu do stosowania siły i przemocy jako instrumentów w rozwiązywaniu zarówno międzynarodowych, jak i wewnętrznych konfliktów?

Kolejny numer czasopisma „Refleksje”, który z dumą Państwu prezentujemy, podejmuje właśnie tematykę konfliktów, głównie politycznych. Wśród opublikowanych artykułów znalazły się również te, które podejmują analizę konfliktu rosyjsko-ukraińskiego we Wschodniej Ukrainie (z jednej strony analizie poddano podłoże ruchów separatystycznych na wschodzie Ukrainy, z drugiej natomiast na przykładzie tego konfliktu omówiono pojęcie wojny hybrydowej). Oprócz tego, autorzy i autorki w swoich opracowaniach odwołują się do konfliktów, które zajmowały społeczność międzynarodową w ostatnich kilku lub kilkunastu latach (m.in. wojna w Iraku, wojna rosyjsko-gruzińska i ruchy separatystyczne w ramach Gruzji). Nie zabrakło również artykułów, które poddają analizie skuteczność działań na rzecz pokoju podejmowanych przez organizacje międzynarodowe (np. działania ONZ na rzecz pokoju w Saharze Zachodniej). Jednak nie tylko klasycznie rozumiany konflikt stał się tematem prezentowanego numeru. Wśród

${ }^{1}$ Porozumienia mińskie to określenie dokumentów podpisanych przez przywódców Rosji, Ukrainy, Niemiec i Francji w 2014 i 2015 r. w Mińsku. Ich celem było określenie warunków rozwiązania konfliktu zbrojnego na wschodzie Ukrainy. Z powodu nierealizowania w pełnie żadnego z postanowień zawartych porozumień, uważa się je nieskuteczną próbę międzynarodowego rozwiązania konfliktu. 
artykułów czytelnicy znajdą również takie, w których nie brakuje odwołań do historii (konflikt Węgry - ZSRR podczas Letnich Igrzysk Olimpijskich w 1956 r.) lub też podejmowana jest kwestia metodologicznych oraz teoretycznych wyzwań, które powinni podjąć badacze zajmującymi się konfliktami zbrojnymi. I wreszcie, tematem prezentowanych opracowań stały się również konflikty stricte polityczne, do których zaliczyć można m.in. te między partiami politycznymi czy też między Kościołem katolickim a państwem. Interesującym wydaje się też być spojrzenie na konflikt od strony wpływu nowych technologii i internetu na działania podejmowane przez strony sporu. Mnogość podejmowanych kwestii gwarantuje wszechstronne opracowanie tematu konfliktu w sferze polityki.

Zapraszamy do lektury.

Natalia Kusa

Redaktorka naczelna 